\title{
EVALUATION OF ALTERNATIVE RAILWAY CONNECTION ACCESS AT JAKARTA SOEKARNO HATTA INTERNATIONAL AIRPORT
}

\author{
Ayu Aprilischa \\ Airport Authority Office IV, Directorate General of Civil Aviation, Ministry of Transportation, Bali, INDONESIA \\ Email: ayu.aprilischa@gmail.com \\ Imam Muthohar \\ Civil and Environmental Engineering Department, Universitas Gadjah Mada, Yogyakarta, INDONESIA \\ Email: imuthohar@mstt.ugm.ac.id \\ Richard Moxon \\ Air Transport Management, School of Aerospace, Transport and Manufacturing, Cranfield University, London, UK \\ Email: r.moxon@cranfield.ac.uk
}

\begin{abstract}
Traveling between the center of Jakarta and Soekarno Hatta International Airport (SHIA) is further constrained by the limited number of main routes available which likely cannot be accommodated in the future by road based transport modes alone. Hence, the airport needs to develop airport surface access to accommodate its network. The aim of this research is to analyze the railway access system for developing the system of SHIA using multi criteria analysis in the selection of alternative route alignment of the railway line and a qualitative study in data collection within the research design. Development of the criteria includes technical, economic, environmental and spatial aspect. Three alternatives have been proposed in this analysis, i.e. through West Jakarta, through North and West Jakarta and through North and Central Jakarta. The results show that alternative 3 (through North and Central Jakarta) can give implications to the airport users, i.e. providing a high standard of the rail link in a well-timed manner and a cost-effective public transport link. Improving the multi-modal access to the airport will improve the supply of employment to business, lead to urban regeneration around station locations, and improve Greater Jakarta Metropolitan Area regional competitiveness.
\end{abstract}

Keywords: Airport Access System, Airport Rail Link, SHIA Railway Access, GJMA Transportation Network

\section{INTRODUCTION}

Airports are an essential resource for the transportation system in view of the fact that they play a major role in transporting people and goods around the world. Airports can be seen as a node that connects air travelers with other modes of transportation to ground travel. In terms of the interrelated connection between air and ground system, it is possible that the quality of access to an airport is likely to influence the demand for its air services.

Aviation demand in Indonesia is growing at a remarkable pace. The biggest airport in Indonesia in terms of the rate of passenger traffic is Soekarno Hatta International Airport (SHIA). SHIA plays a central role in aviation transport of the Greater Jakarta Metropolitan Area (GJMA). Since its commencement of operation in 1985, the number of users of SHIA has grown steadily, and in 2013 the number of passengers reached a record of 53 million, surpassing the airport's capacity.
Traveling between the center of Jakarta and SHIA is further constrained by the limited number of main routes available. At the moment, there is only one high capacity highway connection, namely Prof Sediyatmo highway. Problems that are often experienced at Prof Sediyatmo highway are flooding and traffic jams. The road construction is built on marshy land and is located below the sea level so that when the rainy season arrives, the floods also hit the region. It certainly resulted in disruption of activities at the airport. Incidents such as a breakdown, traffic accident and/or flooding do cause delay and contribute to extensive traffic delays. Such traffic queues can easily propagate in either direction, including towards the Jakarta inner ring road system. Moreover, an increasing number of passengers and cargo transported through SHIA by year also affects the highway users. At certain hours, there is frequent congestion on this highway due to the high number of users and the density of traffic on the motorway network in the city. It is certainly an impact on the level of service of Prof Sediyatmo highway. 


\section{AIRPORT ACCESS SYSTEM}

\subsection{The Role of Surface Access to Airport Development}

Airports are known as major trip generators in a region (Coogan, 2008) and play a significant role in transportation networks by providing connections between the air and surface transport modes (Doganis, 1992). Because of its function as a connection to the airport, airport access systems must provide for a number of different users, including (Ashford, et al., 1997; De Neufville and Odoni, 2003):
a) Passengers
b) Visitors
c) Employees
d) Cargo and mail suppliers
e) Commercials

Airport access is an essential contemplation in the process of planning in order to fulfill passengers' needs in the overall door-to-door travel time (Horonjeff, R., and McKelvey, F.X., 1994). De Neufville \& Odoni (2003) explained that the most challenging part of the passengers' journey is the time to and from the airport since most passengers have experienced the difficulties of an access system and it is usually a complex problem. Therefore, a measurement in minimizing the problem must be implemented by the airport operators.

\subsection{Airport Surface Access Modal Choice}

Several studies of airport surface access mode choices have been carried out in Germany (Pantazis \& Liefner, 2006), Saudi Arabia (Alhussein, 2011), and Taiwan (Jou, et al., 2011). Regarding airport planning and operational management, mode choice has essential implications in the development of landside facilities, strategies to reduce travel share by private car and revenue on car parking and other transportation services (Gosling, 2008). The key issues which affect the mode choice decision to and from the airport (Dimitriou, 2008) could be summarized as follows:

a) Transport cost

b) Total travel time (from terminal to final destination)

c) Number of interchanges to different transport modes

d) Availability of alternatives to private car

e) Quality of transport services

f) Safety and security issues

\section{AIRPORT RAIL LINK}

\subsection{Characteristics of the Airport Surface Access System}

The airport surface access system could be either a simple or very complicated network comprising many nodes with different characteristics, varieties of routes and destinations and combinations of different services. The airport access system refers to any transport model that consists of private cars, taxis, or local mass transit (such as buses, train, and metro). With different characteristics of services, varieties of routes and destinations, airport surface access systems might be either a simple or a complicated network.

\subsection{GJMA Transportation}

GJMA transportation is supported by land, sea and air transportation. The economy growth of GJMA is the highest among other provinces in Indonesia and it has been known as the most congested metropolitan area in Indonesia, especially Jakarta and Bekasi area. Approximately $30 \%$ of the population in GJMA work in Jakarta travel from the surrounding areas in GJMA. Soehodho, et al. (2012) showed that nearly 5 million private vehicles arrive and stay in Jakarta every morning yielding heavy traffic congestion every day within GJMA region. In 2011, it was recorded that there were approximately 13 million vehicles in Jakarta with 11.5 million of private vehicles and the rests consist of public transport, approximately 0.9 million vehicles. In 2010, traffic demand in GJMA was approximately 66 million trips with a composition of modal share of $73 \%$ for private car and $27 \%$ for public transport. If there is no action taken, traffic demand will rapidly increase to 74 million trips in 2020 with a modal share of $78 \%$ for private vehicles and $22 \%$ for public transport.

\subsection{Railway Connections to Airports}

Airports can be connected to the railway network in several ways. In the context of railway services to airports, the location and configuration of the airport station in relation to the air terminal(s) are important in determining the attraction of railway services to passengers. In general, two broad configurations can be identified: one is to build the interchange under the existing air terminal complex, and the other is to build it adjacent to the air terminal and at the same level (Buchanan \& Partners, 1995).

\subsection{SHIA Airport Access System}

Data from Jasa Marga (2008), the operator of the Prof Sediyatmo highway, shows that average number of vehicles traveling to and from SHIA in 2010 was 
159,841 per day. The design capacity of this highway, after the road-widening program, is 150,000 vehicles per day. Therefore, with an estimated average vehicle traffic growth of $9 \%$ per year, gridlock conditions will occur at certain times of the day in the future. Due to its high volume to capacity ratio, travel times can vary greatly on the highway. The average travel time between the airport and central Jakarta is between 40 and 60 minutes for a 28-kilometer journey. However, during extreme congestion or flooding, this journey can easily take three times longer. The analysis of the transport mode share to SHIA is presented in Figure 2. A private vehicle is a dominant mode for trips to SHIA with approximately $40 \%$, followed by taxi $(35 \%)$ and bus (35\%). The use of taxi and bus is prevalent in Tangerang, Jakarta and Bekasi area since currently there is no railway service from SHIA to GJMA region. Travel time from SHIA to the city center in Jakarta takes approximately 30 minutes to one hour without congestion. However, it would take up to 3 hours with congestion and flooding condition.

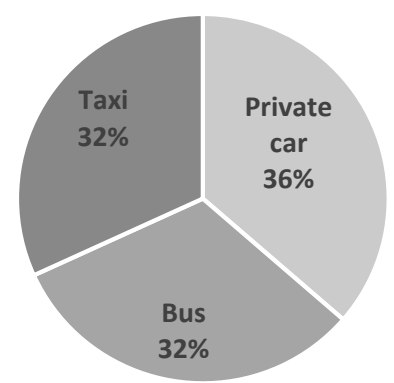

Figure 1. SHIA Surface Access Mode Share

\subsection{Government Proposed Railway Access Plan}

The express service access was identified in the SHIA grand design master plan as a scheme for development of SHIA. SHIA grand design is a master plan to refurbish the existing airport facilities and construct new passenger and cargo terminals, including possible future construction of a third runway (AP2, 2012). The master plan also includes a plan to connect the airport with Manggarai Station (future Jakarta central station) by both an improved commuter railway (extension to Tangerang Line) and a new airport express service that potentially has major benefits for GJMA region (see Figure 3). A recently published proposal under the MOT No. 1264/2013 suggests a dedicated routing between the airports with a city center direction involving connections at Cawang to the east side of the city, through Manggarai, Tanah Abang, Sudirman, and Pluit before terminating at SHIA. The plan is to suggest the route involve construction at elevation with tunneling at either end, where the airports approached.

\section{RESEARCH METHODS}

\subsection{Research Area}

The areas covered by this research include the municipalities and regencies in the Greater Jakarta Metropolitan Area, which consist of Jakarta, Bogor, Depok, Tangerang and Bekasi,

\subsection{Research Data}

The research used secondary data and online research. The secondary data mostly came from the Indonesia Ministry of Transportation, PT. Angkasa Pura 2 and Soekarno Hatta International Airport grand design master plan report.

\subsection{Research Process}

In order to fulfill the research objectives, a methodology framework was designed as Figure 1 below

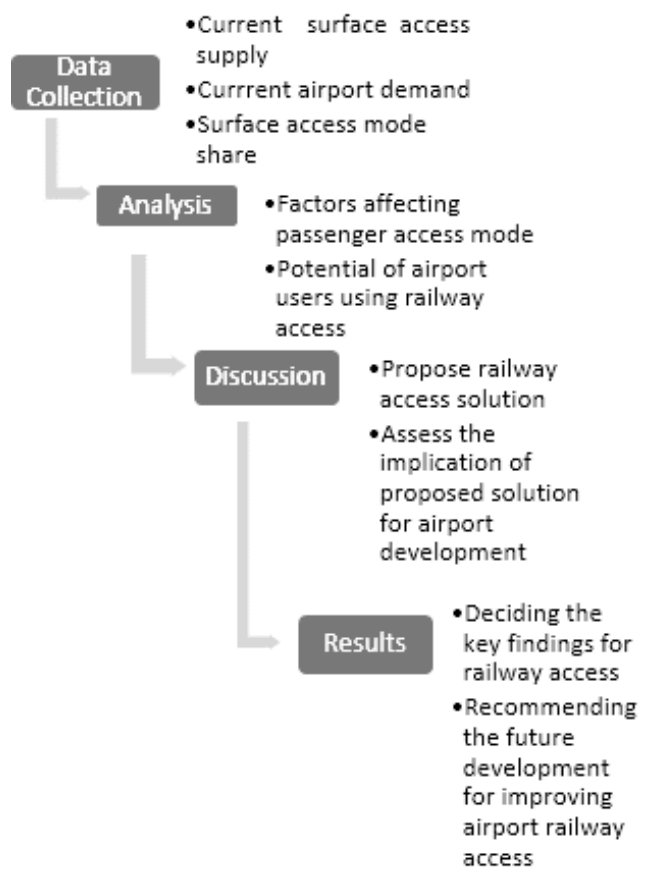

Figure 2. Research Process 


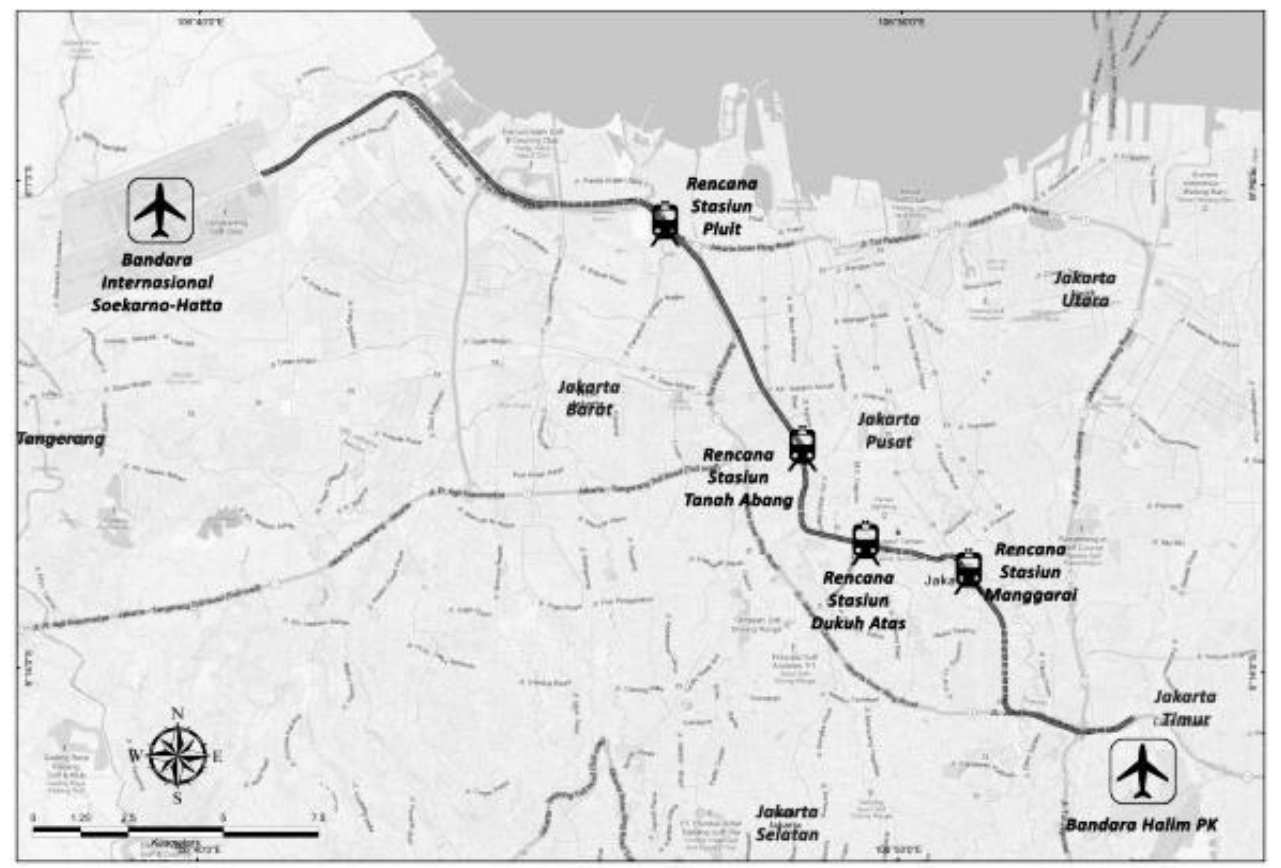

Figure 3. Government proposed railway access

\section{RESULTS AND DISCUSSIONS}

\subsection{Railway Access Development Options}

This research will analyze the alternative route of railway access development at SHIA, apart from the government plan. The railway access at SHIA is a part of the SHIA grand design master plan. I this master plan, there will be an integrated building which p rovides connection to Terminal 1, Terminal 2, and Terminal 3. This building will be located in between Terminal 1 and Terminal 2, as shown in Figure 3. This building does not only serve as a connector but also will be equipped with various facilities, such as railway stations, bus terminals, malls, hotels, and parking areas. This building will be as a terminus station of public transport access to SHIA, which is convenient for airport users. Hereafter in this research, this building will be specifically known as SHIA station. Moreover, it is planned that SHIA will feature a people mover system to connect an integrated building with the terminals and other public transportation systems, allowing airport users to travel into the city center.

\subsection{SHIA Express Service}

The direct rail link between SHIA and GJMA in this research will be elaborated apart from the proposed plan by the government. In this research, several assumptions have been made to determine airport rail link express services in this scheme based on information obtained from transport experts and the government plan. The assumptions made are:

a) The service is dedicated to connecting the airport and the city center.

b) The service is targeted primarily to serve air passengers (with/without baggage) who will place particular importance on speed, reliability, and comfort as well as who may be expected to pay a premium fare for such a service.

c) The service intends to provide a more reliable and comfortable environment for passengers than alternative modes of transport under average traffic conditions in about 30 minutes maximum.

d) It has been assumed that some of SHIA Express station will be constructed adjacent to the various existing station in order to minimize the operational cost and will have convenient interchanges with other railway lines.

e) The service will use the double spur rail configuration which suitably accommodates rail service scenarios.

f) The service will connect SHIA and HPK airport with limited stop services

This research has identified alternative route alignment and proposed a preferred alignment. Three options of route alignment were selected for multi criteria analysis. There are alternative 1 , alternative 2 and alternative 3. Alternative 1 is planned as an express network that is approximately $41 \mathrm{~km}$ long. It consists of five stations, namely SHIA, Kedo Dukuh Atas, Manggarai and HPK airport (see Figure 4). These lines 
will need the infrastructure of the railway track which planned to be built alongside with the highway and ring road. This alignment will be operated from SHIA station in the integrated building to the west of Jakarta where it serves Kedoya station. The line then runs along the central side of Jakarta where it serves Dukuh Atas and Manggarai station before terminating at HPK station.

Alternative 2 is planned as an express network that is approximately $38 \mathrm{~km}$ long. It consists of six stations, namely SHIA, Pluit, Toman Semanggi, Pancoran, and HPK airport (see Figure 5). These lines will need new infrastructure the railway track which is planned to be $\mathrm{b}$ alongside with the highway and ring road. The alignment will be operated from SHIA station in the integrated building to the West Jakarta where it serves Pluit station. The line then runs along to the south of Jakarta where it serves Tomang, Semanggi and Pancoran station before terminating at HPK station.

Alternative 3 is planned an express network that is approximately $36 \mathrm{~km}$ long. It consists of four stations, namely SHIA, Jayakarta, Manggarai, and HPK airport (see Figure 6). Some of the lines will run adjoining the existing commuter line, while others will need the new infrastructure of the railway track which is planned to be built alongside with the highway. This alignment will be operated from SHIA station in the integrated building to the west of Jakarta where it serves Jayakarta station. The line then runs along the central side of Jakarta where it serves Manggarai station before terminating at HPK station.

Multi criteria analysis is a simple analysis using criteria as attributes assessment, can be either qualitative or quantitative assessment. Broadly speaking, the MCA activity consists of several main steps namely: setting goals, criteria, weighting criteria and scoring alternative decisions relating to the criteria. For the case of election of the railway line, which was developed among other criteria: technical criteria, economic criteria, criteria of environmental and spatial criteria. Each criterion that has been evaluated is divided into sub-criteria, and then each sub-criterion has indicated qualitative and quantitative indications, each of which is equipped with an indication of the value attribute. The result of the assessment is a total score of each alternative decision. Ranking the priority of various alternative decisions can be prepared based on the total score. According to the result using multi criteria analysis, alternative 3 has been selected as an alternative route alignment of SHIA Express. This result is selected based on criteria of multi criteria, i.e. technical criteria, economic criteria, criteria of environmental and spatial criteria.

SHIA Express will operate daily 24-hour and 365 days per year. SHIA Express will be relatively frequent, preferably with an interval between trains in the peak time of no more than 10 minutes. The extended operation may be required on a 24-hour basis during special event days. Operation speeds of airport rail link in Asia vary from $120 \mathrm{kph}$ to $160 \mathrm{kph}$. An operation speed of $135 \mathrm{kph}$ is proposed, which is the same as the Hong Kong Airport Rail link and at the mid-range of the Asia airport rail systems. The time from each origin and destination to each SHIA Express station was considered in the overall journey for the airport rail link. Average travel times to and from SHIA on this proposed operation plan are presented in Table 1 below.

Table 1. SHIA Express Average Travel Time (minutes)

\begin{tabular}{cc}
\hline Station & Time $(\min )$ \\
\hline Jayakarta & 13 \\
Manggarai & 21 \\
HPK Station & 27 \\
\hline
\end{tabular}

A fare structure to allow business passengers to travel to intermediate stations may be implemented, but the fare needs to be high enough to discourage normal commuter passengers from overloading trains. The government has proposed a fare for SHIA Express of IDR 90,000 (USD 9.3) and would be the same fare between any inner town station and SHIA. The value of this fare is reasonable as a result of comparison with transportation modes including fuel, highway, taxi, and bus fares. On the other hand, this fare is lower than or competitive with the taxi as the target market.

\subsection{SHIA Commuter Service}

The commuter line would provide a commuter service similar to suburban trains in Jakarta. The line would have frequent stations and would likely be very attractive, particularly for airport employees living in the Tangerang areas. It is estimated that this service would offer opportunities to airport employee relevance to SHIA and the express connect the existing (to be upgraded) Tangerang Line with SHIA. This proposed line would join the Tangerang line and run trains from SHIA into central Jakarta. Several assumptions are being used to determine commuter services in this scheme. The assumptions are:

a) The service is targeted primarily to serve airport employees and suburban passengers who live in the vicinity of the airport area. 


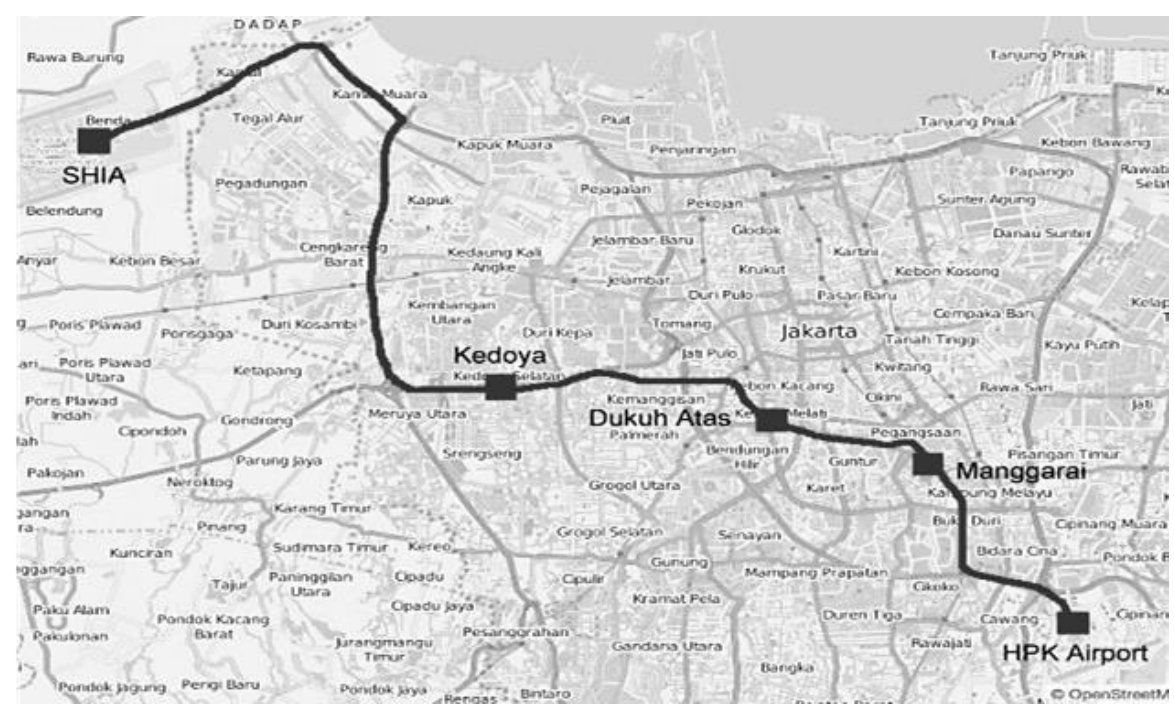

Figure 4. Alternative Route 1 of SHIA Express

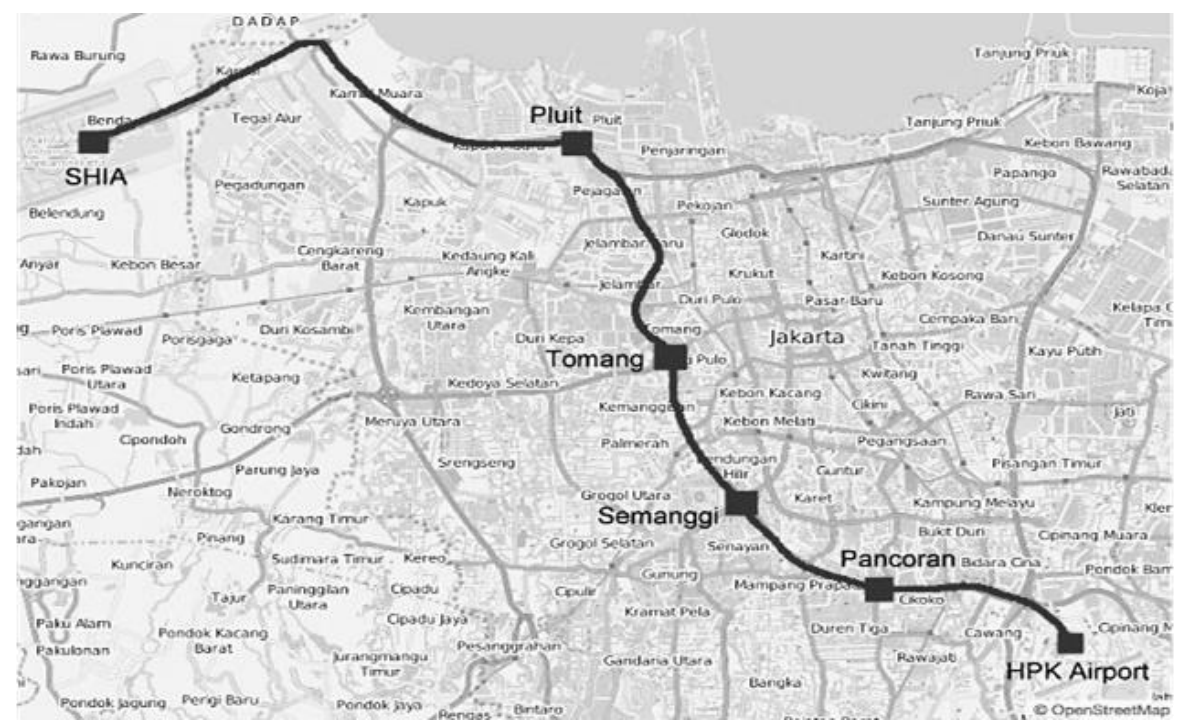

Figure 5. Alternative Route 2 of SHIA Express

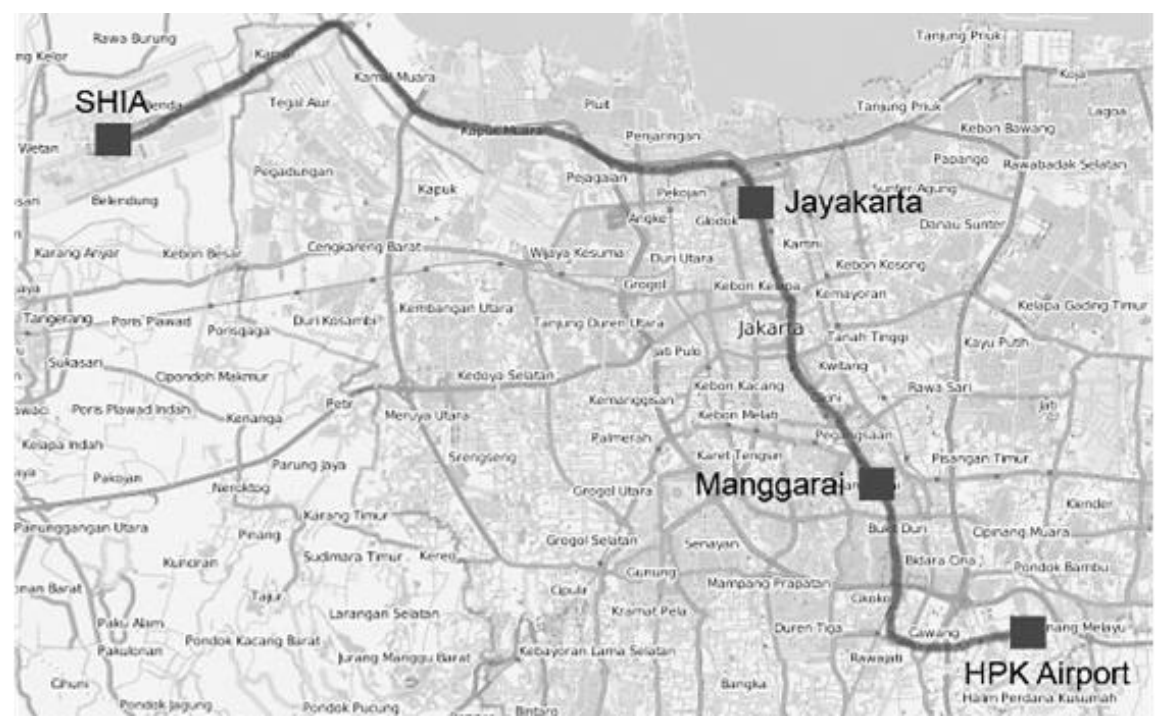

Figure 6. Alternative Route 3 of SHIA Express 
b) The service would be, however, much less attractive for air passengers who would be willing to pay for an express service and have destinations to the southern or eastern Jakarta, Bekasi, Depok, and Bogor.

c) Airport employees are likely to arrive in the hour before their work commences.

There will be a new railway track from SHIA station to Tangerang station, and the rest station will use the current comuter station as shown in Figure 7.

SHIA Commuter is estimated to operate daily from 05:00 a.m. to 01:00 p.m., as the airport employees are likely to arrive in the hour before their shift commencing. During the special event, the operation would be extended to 24 hours. Although using the same electric train, operation speed for SHIA Commuter is slower than SHIA Express due to differences of train type. Operation speed for commuters is an average of $40 \mathrm{kph}$ and maximum of $90 \mathrm{kph}$. With the proposed operation plan, journey time for SHIA Commuter is expected approximately 43 minutes to the city center of Jakarta, detailed in Table 2.

Currently, the fare for commuter line services from Duri station to Tangerang is approximately IDR 4500 (USD 0.47) which has been subsidized by the government of Indonesia. However, for SHIA Commuter services, commuter line fare will be commercialized without subsidy. The fare of direct electric rail from SHIA to the city center will be commercial in accordance with the economic value. This fare will be the same with the fare of airport rail link at Kualanamu airport, but the amount of the fare has not been decided. In spite of this, it is assumed the fare would be less than the fare of SHIA Express services.

Table 2. SHIA Commuter Average Travel Time (minutes)

\begin{tabular}{cc}
\hline Station & Time (min) \\
\hline Tangerang & 8 \\
Poris & 16 \\
Kalideres & 21 \\
Bojong Indah & 28 \\
Pesing & 35 \\
Duri & 43 \\
\hline
\end{tabular}

\subsection{Automated People Mover System}

The government is envisaged that the integrated building in SHIA will be connected to terminals of the airport by means of automated people mover system, providing fast, high frequency, high capacity connections to terminals of the airport in a seamless and integrated way. The use of automated people mover systems free up valuable space close to terminals that can be used for critical airport functions rather than for roads and bus stations. The government predicted that the speed would be approximately $30 \mathrm{~km} / \mathrm{h}$ to $50 \mathrm{~km} / \mathrm{h}$. To consider journey time of automated people mover system, the following access times from integrated building were assumed for all terminals as shown in Table 3 .

Table 3. Automated People Mover Average Transfer Time

\begin{tabular}{ccc}
\hline Terminal & Distance $(\mathrm{km})$ & $\begin{array}{c}\text { Transfer Time } \\
(\mathrm{min})\end{array}$ \\
\hline Terminal 1 & 2 & 5 \\
Terminal 2 & 2 & 5 \\
Terminal 3 & 3,5 & 7 \\
\hline
\end{tabular}

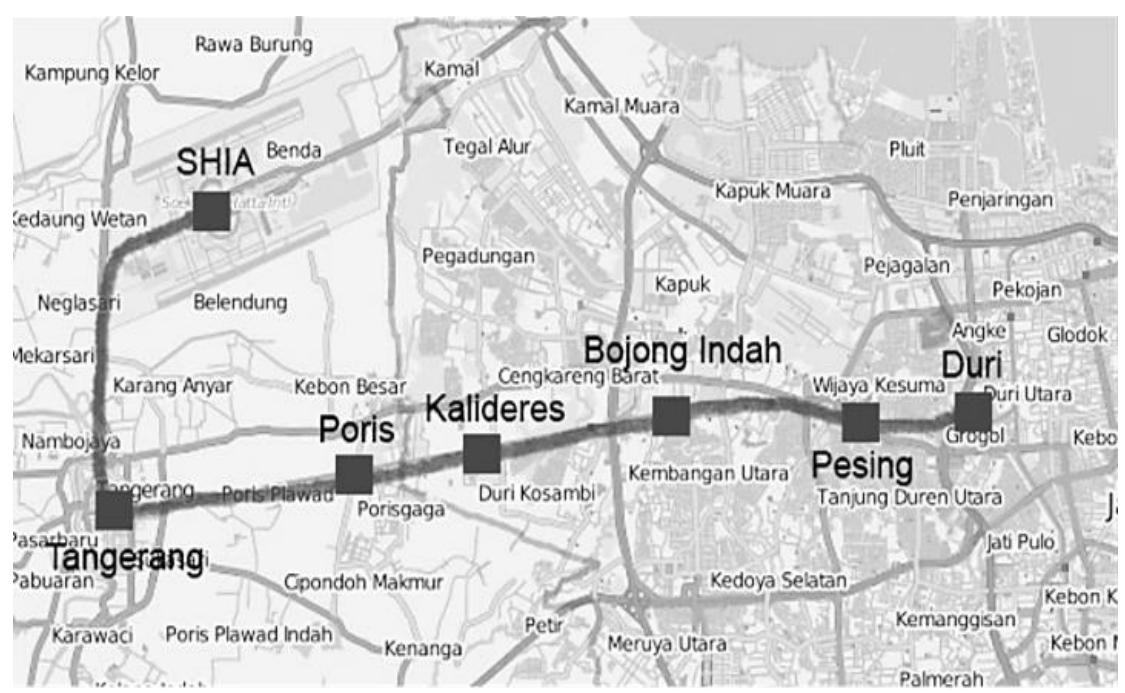

Figure 7. SHIA Commuter Line 


\subsection{Railway Access Assessment}

The purpose of railway access assessment is to evaluate airport rail links (both SHIA Express and SHIA Commuter) corridor to SHIA airport.

a) High Standard, Punctual, and Cost-Effective Public Transport Link

The propose of this assessment is to provide a high standard of the rail link in a well-timed manner and cost-effective public transport link measured by travel time within SHIA and GJMA and comparative cost analysis.

By delivering mode shift from road to the railway, it is predicted road congestion would be reduced. In addition, would generate benefits from travel time for those who access the airport by car, bus, and taxi. It has been proposed that SHIA Rail Link would be operated by Electric Multiple Units (EMU) trains and on the line at speeds up to $135 \mathrm{kph}$ for SHIA Express and 40kph for SHIA Commuter. The proposal of rail services will offer travel times to SHIA typically around 30 minutes to 1 hour faster than current journey times for airport users, including air passenger, airport users, and escorts. Indicative travel times for SHIA Rail Link through each line were calculated compared with other current transport modes. Table 4 shows travel time of various airport rail links in off-peak time compared to the road travel time (Coogan, 2008).

Table 4 Rail Share of International Airport Rail Link

\begin{tabular}{llllll}
\hline \multirow{3}{*}{ Airport } & Road & Rail & Ratio & Distance \\
& travel & travel & (road & from & Fare \\
& time & time & /rail & CBD & structure \\
& & & travel & $(\mathrm{km})$ & \\
& & & time) & & \\
\hline
\end{tabular}

London

Heathrow

- Express

- Tube

45

45

15

London

80

45

3

25

25

Flat

Gatwick

Amsterdam 30

30

2.7

49

Zonal

Flat

Kuala Lumpur 50

17

1.8

20

Flat

Bangkok

\begin{tabular}{llllll}
$\begin{array}{l}\text { Express } \\
\begin{array}{l}\text { City line } \\
\text { Jakarta* }\end{array}\end{array}$ & 30 & 16 & 2 & 25 & Flat \\
$\begin{array}{l}\text { Express (north60 } \\
\text { line) }\end{array}$ & 21 & 2.8 & 36 & Flat \\
$\begin{array}{l}\text { Commuter } \\
\text { (south line) }\end{array}$ & 60 & 43 & 1.4 & 12 & Distance \\
\hline
\end{tabular}

Based on the result, airport users would reduce travel times generally around 40 to 60 percent faster than car, taxi, or bus options. SHIA Rail Link is likely to fit within this range. In addition, the results indicate that SHIA Rail Link provides the best travel time to SHIA from city center compared with other current transport modes among the North and South line. By reducing travel time for business trips using SHIA Express and airport employee trips using SHIA Commuter, SHIA Rail Link is expected to improve productivity and reliability of journeys by rail to SHIA. Although a full analysis of these benefits is not yet available, it is estimated the benefits may influence some segments of this market. Moreover, there is an indication that the total value of journey time benefits may have related with the proposed solution of rail services would come to more efficient, reliable, and comfortable journeys for airport users.

The cost estimation has been calculated including the construction works, electrical works, signal and telecommunication system, track, rolling stock, and land acquisition. To estimate unit prices of SHIA Rail Link, this analysis used a unit price to be developed that would reflect current pricing levels based on nationally recognized productivity and local equipment rates. Equipment, material, and supply prices were obtained from the Indonesian Railway and local suppliers resources. Due to the limited data/ information from the resources, it is assumed the rates have inflated per year based on the historical data from the Indonesian Railway during 2008 to 2010. SHIA Express has an estimated total cost of approximately IDR 6,078 billion (USD 518 million) and IDR 1,768 billion (USD 151 million) for SHIA Commuter. From this result, SHIA Express has the higher cost than SHIA Commuter due to the construction of new track alignment of SHIA Express services. In other words, based on the result, it can be seen that the estimated cost of this project costs comparatively lower compared to the total cost planned by the government. Due to adjoining construction with the existing rail track, this project is cheaper than the government plan. What the government has planned is that the project will be built on the new rail track which causes more land acquisition requirements.

Regarding this analysis, SHIA Rail Link will reduce reliance on car travel that might have impacts on congestion. The government predicted rail mode share at SHIA would be up to 30 percent as a result of introducing airport rail link service, which captures 18 percent in SHIA Express and 12 percent in SHIA Commuter. In this case, sensitivity analysis will be undertaken 10 percent under and upper from the 
Government prediction. With the analysis of 20 percent rail mode share, once SHIA Rail Link is operational, SHIA Express would capture 12 percent mode share and 8 percent for SHIA Commuter. On the other hand, with 40 percent mode share, SHIA Rail Link would capture 24 percent in Express services and 16 percent in Commuter services. See Figure 8. It is obvious that SHIA Rail Link is unlikely to attract the $30-40$ percent of mode share comparable with the most successful airport rail links. The existing transport network and urban layout are not as small European cities nor does it benefit from a remote location, like Narita or Oslo, which discourages use of taxis. A mode share for SHIA Rail Link between 20 - 30 percent seems realistic, depending on a number of factors including further deterioration of road travel time, improvements to bus services, and functionality of intermodal operations at rail stations.

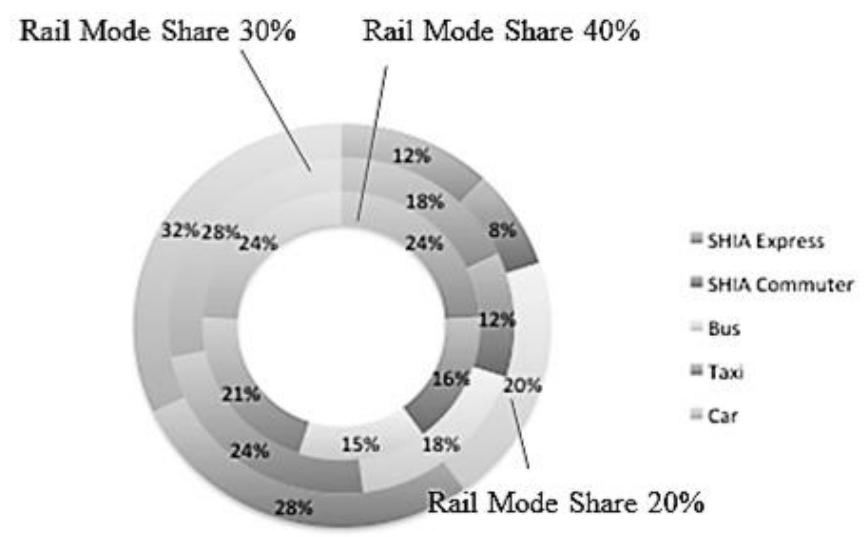

Figure 8. Proportion of mode share at SHIA

b) Support the Integration of Rail Link in Environmental, Business Activity, and Wider Economic Benefits

Improving the multi-modal access to the airport will improve the supply of employment to business, lead to urban regeneration around station locations, and improve GJMA's regional competitiveness. A qualitative assessment has been made on these wider impacts using international research and economic data for the region.

As a consequence by delivering road-rail substitutions, it is projected that SHIA Rail Link would have reduced local emissions from traffic noise and air pollution on local communities. SHIA Rail Link is proposed to improve air quality, as the railway system may reduce vehicle utilization and could result in a cumulatively lower level of emissions. It also has potential to decrease noise nuisance and decrease traffic nuisance since airport rail link will directly reduce private vehicle utilization with potential positive outcomes in GHG emissions.

The proposal of SHIA Rail Link would likely lead to improved accessibility and reduced road congestion. The latter issue is of major concern in the Jakarta area where local movement and congestion sit alongside the long- distance strategic traffic movement of both passengers and freight. Improved traffic conditions along the airport access roads in the North Jakarta will allow freight vehicles to operate more efficiently along these routes. This will make the best use of existing transport network capacity and lead to potential improvements in business logistics, time and cost savings, reliability, and other operational efficiency gains. It is predicted that SHIA Express will create business opportunities for GJMA region, especially Jakarta, Bekasi, and Bogor regions. In contrast, SHIA Commuter derives accessibility benefits more widely to Tangerang regions - in particular where the increased accessibility provided by this service allows more jobs to be created and existing jobs to become more productive.

By placing SHIA with the high level of rail service, SHIA Rail Link will enable the existing major centers of economic activity to gain from improved access to each other. JICA (2014) reported the total GRDP of GJMA coming from the economic production amounted to USD 89 billion in 2007, consisting of 71 percent from Jakarta, 12 percent from Bekasi, 9 percent from Tangerang, and 8 percent from other municipalities and regencies in GJMA. Of this total figure, Jakarta contributes most of the GJMA economy compared with other areas. However, the GDP of Jakarta will be at 22 percent stable between 2012 and 2030, although it is predicted Jakarta will grow as a megacity, with a population of over 10 million people.

On the other hand, SHIA Commuter would improve the access to airport employment and economic activity of local business in the Tangerang and Jakarta area. As mentioned in Section 4, most of the airport employees lived in Tangerang area due to the proximity of this area to the airport. A large-scale employment area might be as well supported as other areas due to the need for airport rail link.

\section{CONCLUSIONS}

The results show that alternative 3 has been selected in SHIA Express service based on multi criteria analysis as the alternative route alignment on railway connection access at Soekarno Hatta International Airport. Moreover, the railway access both Express and 
Commuter service at Soekarno-Hatta International Airport can lead to implications for the airport users. The implications are providing a high standard of the rail link in a well-timed manner and a cost-effective public transport link, which are measured by travel time within Soekarno-Hatta International Airport and Greater Jakarta Metropolitan Area and comparative cost analysis on this project. In conclusion, improving the multi-modal access to the airport will improve the supply of employment to business, lead to urban regeneration around station locations, and improve Greater Jakarta Metropolitan Area regional competitiveness.

\section{REFERENCES}

Alhussein, S. N., 2011. Analysis of Ground Access Modes Choice King Khaled International Air- Port, Riyadh, Saudi Arabia. Journal of Transport Geography, pp. 1361-1367.

Ashford, N., Stanton, M. \& Moore, C., 1997. Airport Operations. New York: Mc Graw-Hill.

Buchanan \& Partners, 1995. Optimising Rail/Air Intermodality in Europe, London: European Commission - DG III.

Coogan, M., 2008. Ground Access to Major Airports by Public Transportation, Washington, D.C.: Transportation Research Board of the National Academies.

De Neufville, R. \& Odoni, A., 2003. Airport Systems: Planning, Design, and Management.. London: McGraw-Hill..

Dimitriou, 2008. Airport Accessibility: Measuring Surface Access Performance, London: Cranfield University.

Doganis, R., 1992. Chapter 8: Monitoring Airport Performance and Efficiency. In: The Airport Business. London: Routledge, pp. 158-187.

Gosling, G., 2008. Airport Ground Access Mode Choice Models, Washington, D.C.: Transportation Research Board of the National Academies.

Horonjeff, R., and McKelvey, F.X., 1994. Airport Planning, Planning and Design of Airports. New York: McGraw-Hill.
JICA, 2014. Contributions during 60 Years of International Cooperation, JICA: Japan International Cooperation Agency.

Jou, R., Hensher, D. \& Hsu, T., 2011. Transportation Research Part E: Logistics and Transportation Review. In: Airport Ground Access Mode Choice Behavior after the Introduction of A New Mode: A Case Study of Taoyuan International Airport in Taiwan. s.1.:s.n., pp. 371-381.

Pantazis, N. \& Liefner, I., 2006. The Impact of Lowcost Carriers on Catchment Areas of Established International Airports: The Case of Hanover Airport. Germany: Elsevier Ltd..

Soehodho, et al., 2012. Transport Mode Choice by Land Transport Users in Jabodetabek (Jakarta-BogorDepok-Tangerang-Bekasi): An Urban Ecology Analysis. [Online]

Available at:

http://psrcentre.org/images/extraimages/412625.pdf

[Accessed 3 July 2013]. 